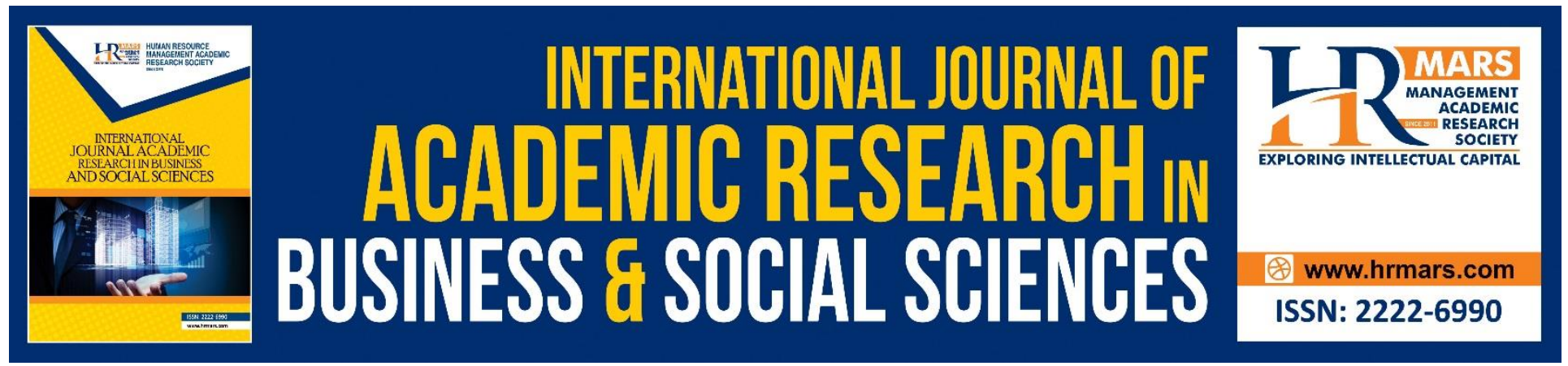

\title{
Understanding the Dimension of Job Resources, Personal Resources and Transformational Leadership in Boosting Work Engagement Level among Employees in Public Sector
}

Zaki Zakaria, Khairuddin Idris, Bahaman Abu Samah, Norhasni Zainal Abiddin

To Link this Article: http://dx.doi.org/10.6007/IJARBSS/v8-i10/4797

DOI: $10.6007 /$ IJARBSS/v8-i10/4797

Received: 08 Sept 2018, Revised: 13 Oct 2018, Accepted: 22 Oct 2018

Published Online: 10 Nov 2018

In-Text Citation: (Zakaria, Idris, Samah, \& Abiddin, 2018)

To Cite this Article: Zakaria, Z., Idris, K., Samah, B. A., \& Abiddin, N. Z. (2018). Understanding the Dimension of Job Resources, Personal Resources and Transformational Leadership in Boosting Work Engagement Level among Employees in Public Sector. International Journal of Academic Research in Business and Social Sciences, 8(10), 1035-1051.

\section{Copyright: (C) 2018 The Author(s)}

Published by Human Resource Management Academic Research Society (www.hrmars.com)

This article is published under the Creative Commons Attribution (CC BY 4.0) license. Anyone may reproduce, distribute, translate and create derivative works of this article (for both commercial and non-commercial purposes), subject to full attribution to the original publication and authors. The full terms of this license may be seen

at: http://creativecommons.org/licences/by/4.0/legalcode

Vol. 8, No. 10, 2018, Pg. 1035 - 1051

Full Terms \& Conditions of access and use can be found at http://hrmars.com/index.php/pages/detail/publication-ethics 


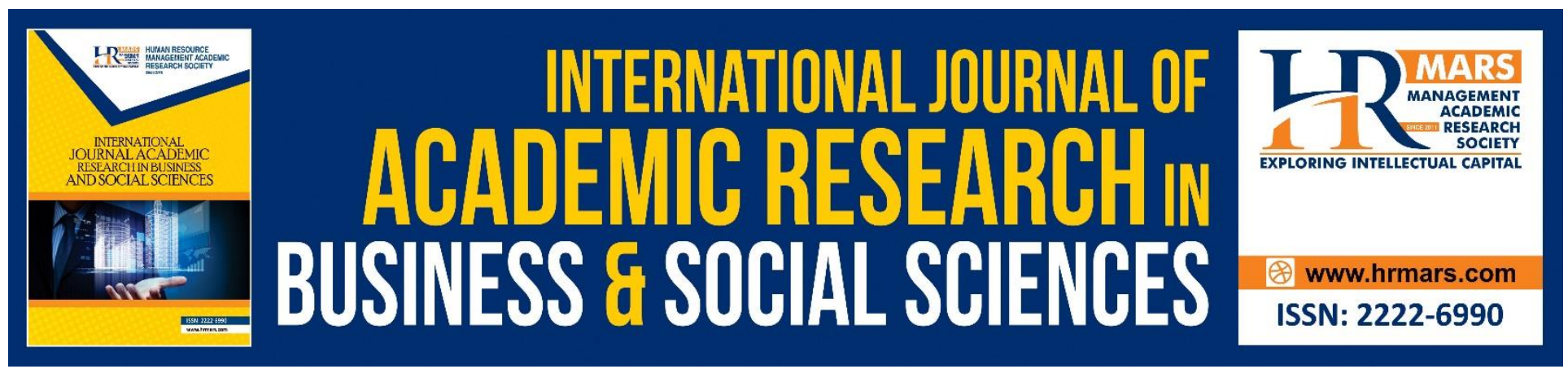

\title{
Understanding the Dimension of Job Resources, Personal Resources and Transformational Leadership in Boosting Work Engagement Level among Employees in Public Sector
}

\author{
Zaki Zakaria, Khairuddin Idris, Bahaman Abu Samah, Norhasni \\ Zainal Abiddin
}

Faculty of Educational Studies, Universiti Putra Malaysia, 43400 UPM Serdang, Selangor Darul Ehsan, Malaysia

\begin{abstract}
Work engagement is the envy of many organizations. The argument is simply based on numerous benefits it offers on plate. Many studies have confirmed that work engagement has massive influence for various positive results that leads towards better performance of individual and organizations. For Malaysian public service employees, they have been identified as the primary facilitators in ensuring all government initiatives and programmes are carried out effectively. This has been outlined in the Government Transformation Programme (GTP) as Malaysia has bold intention towards becoming a fully developed nation by 2020. Thus, public servants must be fully engaged in their daily activities as this the key towards recording excellence performance as wish by citizen and stakeholder. However, several reports from multiple organizations regarding that Malaysia has recorded low percentage of having engaged workforce. This scenario needs urgent attention as disengaged employees are associated with many negative consequences such low productivity, high turnover and even drive customers away. From the public service perspective, the future of our nation building is at stake. Based on literature reviews, job resources, personal resources and transformational leadership have profound impact towards increasing level of engagement among employees. Hence, understanding on certain dimension of the aforementioned three variables above is vital as they are able to explain work engagement among public servants.
\end{abstract}

Keywords: Work engagement, public service, job resources, personal resources and transformational leadership 
INTERNATIONAL JOURNAL OF ACADEMIC RESEARCH IN BUSINESS AND SOCIAL SCIENCES

Vol. 8, No. 10, Oct. 2018, E-ISSN: 2222-6990 @ 2018 HRMARS

\section{INTRODUCTION}

People are unique in a sense it cannot be duplicated or imitated by competitors. In fact, it is the most valuable asset for any organization if being properly managed. One of the effective ways to get the best result from employee is to ensure that they are engaged with their role performance. Thus, fostering engagement among employees in any organization is vital towards meeting organizational goals. Public servants in Malaysia are expected to play a major role in facilitating Malaysia towards becoming a fully developed nation in 2020. This has been outlined in Government Transformation Programme (GTP) that was launched in 2010. However, achieving this vision is an ardours task. It needs strong commitment, energetic and highly engaged public service workforce to ensure this noble vision attainable.

There are simply many reasons why employers need engaged workers. This is due to massive benefits of work engagement can provide for individual development and organizational growth. Many studies have confirmed that work engagement contributes significantly for various positive outcomes. At organizational level, this construct are related towards many positive result such as recording less turnover, producing more engaged staff, improving the company's financial position and contributing to the general success of the organization (Salanova, Agut \& Peiro, 2005). Moreover, work engagement also has been identified as powerful indicator for company health and long term performance (Bazigos \& Harter, 2016). Both of them also mentioned that increasing level of engagement can be described as improving customer satisfaction, increasing growth revenues and producing better products. In terms of individual benefits, work engagement is proven to be the leading indicators in recording better outcomes in the forms of reducing absenteeism rate, reducing employees turnover and relate to positive association with daily task and overall health (Boldani, 2013). Surprisingly enough, engagement also promoted bottom-up innovation among employees at workplace (Bazigos \&Harter, 2016).

Despite of many advantages of work engagement, research undertaken by Gallup (2013) pointed out that the engagement level among employees worldwide remains poor. In fact, their studies found there were only 13 percent engaged employees around the globe. The other 63 percent fall under disengaged category and the remaining 24 percent are actively disengaged group. Malaysia performance is not even better. Gallup's (2013) reported that Malaysia has among the highest proportion of disengaged employees in the world. In our case, Malaysia was recorded with having only a small 11 percent of engaged employees. The remaining 89 percent categorized as disengaged (81\%) and actively disengaged employees (8\%).

Other related studies from different organizations also pointed out towards the same conclusion that is low representation of engaged employees in Malaysia. For example, a study undertaken by International Data Corporation (IDC) that is based in Singapore in 2016 found out that only 23 percent of Malaysian professionals are engaged and satisfied at work (Jiminez, 2016). In fact, this percentage was the lowest engagement rate across the Asia Pacific region compared to Australia (42\%), Philippines (59\%) and India (59\%). Another separate survey undertaken by Jobstreet.com in July 2016 found out that nearly 52 percent of Malaysians employees belong to the disengaged group, 23 percent choose to be neutral and only 23 percent are engaged group termed as 'happy employees category' (New Straits Times, 2016). Finally, the latest study by AON Corporation regarding trends in 
global employee engagement report 2017 placed Malaysia and Singapore as having the least engaged employees among major Asian markets (HR Asia, 2017).

As for the public sector, the consequences are massive. As our nation is gearing towards Vision 2020, having a large pool of disengaged workforce in the public service will not help. Therefore, understanding variables that can boost work engagement rate among public service staff is the prime key in recording high rate of successful implementation of our national agendas and aspirations.

\section{Concept of Work Engagement}

Many scholars have agreed on principle that work engagement has unique characteristics that directly influence positive impact towards individual and organizational performance. As such, work engagement is closely related to state of mind which is characterized by vigor, dedication, and absorption (Schaufeli, Pinto, Salanova \& Bakker, 2002). Vigor is associated with feeling energetic, strong mental and able to put more effort than required in order to complete the task. Dedication can be referred as having the feeling of importance, highly committed, high motivated, readily inspired and able to take challenges. Meanwhile, absorption is being fully concentrated and heavily attached in his role performance. For Khan's (1990) who introduced the concept of engagement, he mentioned that this construct is strongly related to employee psychological aspect in which employees invest in their physical, cognitive and emotional resources during work performance. He also stated that employees portray strong job performance at the workplace in the presence of three psychological conditions that are related to meaningful experience, safety and availability.

Schaufeli and Bakker (2001) explained the construct of work engagement is functional work involvement that associates hard work with enjoyment of the duties. In essence, work engagement is a powerful construct that manifested as energy, involvement and focus among employees in meeting organizational goals and objectives (Macey and Schneider, 2008; Schaufeli, Salanova \& Gonzalez, 2002). Schaufeli and Bakker (2010) explained work engagement as the relationship of employees with their works in terms of involvement, commitment, passion, enthusiasm, absorption, focused effort and energy. Based on various explanations from scholars on this construct, it is simply hard to get the consensus on work engagement definition and concept (Bakker, Simon \& Leiter, 2011). However, most scholars agreed that it is related to energy, involvement and willingness of employees in ensuring organizational goals can be achieved.

\section{Benefits of Work Engagement}

Work engagement has tremendous positive impact on occupational well being at both personal and organizational level (Bakker \& Demerouti, 2008). Previous studies have confirmed that work engagement matters to performance such as customer satisfaction (Salanova, Agut \& Piero, 2005), improving both informal and formal role of performance (Schaufeli, Taris \& Bakker, 2006) and lower intention to quit (Schaufeli \& Bakker, 2004). It also has significant impact on personal consequences in terms of increasing happiness, enthusiasm, joy and optimism (Bakker \& Demerouti, 2008). The list of its importance does not end here. Work engagement has also been shown to have help employees to stay focused, becoming energetic and connected to their role performance. More 
importantly, this construct also leads employees towards feeling of competency, able to overcome job demands and keeping burnout at bay (Leiter \& Maslach, 1988).

Interestingly enough, work engagement among employees will lead towards the formation of engaged employees. According to May, Gilson, and Harter (2004), engaged employees are able to perform at high intensity due to their burst of energy and enthusiasm in carrying out their duties. In fact, they are unique as they enjoy their time at workplace and not job addicted like other workers. Meaning to say, they are having fun at work and enjoy doing other things outside work. Saks (2006) explained that the term engagement is not an attitude but refers to an individual that is attentive and absorbed in his role performance at work. He further explained that engagement is a unique construct that is associated with cognitive, emotional and behavioural component that determine employees role performance.

A study by Macey and Schneider (2008) concluded that engaged employees are dedicated, energetic, engrossed in their tasks and feel time flies during role performance. In addition, research undertaken by Jim Harter from Gallup Group found out that those who are engaged at the workplace have the feeling of indebtedness towards their organizations. In this scenario, these staffs perform at their best abilities as they possess a strong personal feeling that it is their duty and responsibility in ensuring organizational objectives can be achieved. This can be translated to having employees that are more attentive, vigilant and willing to support their buddies and the organizational needs (Boldani, 2013). In conclusion, the importance of work engagement is simply massive and can contribute significantly towards attaining both personal development and organizational objectives.

\section{Major Issues in Public Services}

The Malaysian Government has introduced many initiatives to implement public service transformation in its quest to deliver better and efficient services to the people. For instance, the introduction of Key Performance Index (KPI) in 2004 form as a basis to benchmark the performance for all ministries and agencies in public service (Johari, Mit \& Yahya, 2009). On top of that, the formation of National Integrity Plan (NIP) in 2004 also aims at reducing corruption, mismanagement, power abuse besides enhancing the efficiency of service delivery and improving corporate governance. In showing the seriousness of government transformation initiatives, The Honorable Prime Minister launched several transformation programmes in 2010 such as "1 Malaysia: People First, Performance Now", GTP, Economic Transformation Programme (ETP) and introduced National Key Result Area (NKRA) as a platform to enhance service delivery to people (Rosli, Aziz, Mohd \& Said, 2015). Later on, the government has taken an initiative to implement the National Blue Ocean Strategy (NBOS) in the current Eleventh Malaysia Plan (2016 - 2020). This is the strategy that focuses on delivering high impact project at low cost and rapidly executed. The Eleventh Malaysia Plan also lays foundation for public sector to play pertinent role in building a better Malaysia for all Malaysians (Eleventh Malaysian Plan, 2015).

However, issues lingerig over the public service is far from over. As reported by Abdullah, Sulong and Said (2014), there are still major issues concerning accountability, integrity and ethical behaviours among government staff. For instance, corruption cases among government employees is like a cancer that has spread to many government agencies either at federal, state or district level. The number of public servants getting caught for graft is increasing. According to Malaysian Anti- 
INTERNATIONAL JOURNAL OF ACADEMIC RESEARCH IN BUSINESS AND SOCIAL SCIENCES Vol. 8, No. 10, Oct. 2018, E-ISSN: 2222-6990 @ 2018 HRMARS

Corruption Commission (MACC), corruption among government employees is rampant and need strong will to tackle this issue. As mentioned by MACC (Prevention), Datuk Shamshun Baharin Mohd Jamil during a talk at the Ministry of Rural and Regional Development, nearly 50 percent of the 2,329 graft cases from 2014 - 2016 are made up of civil servants. In 2016 alone, there number of investigation paper alone stood out at 665 cases against government staff. As of February 2017, MACC has detained 548 government staff for bribery. This proves that corruption among government staff is a serious matter that needs to be addressed comprehensively by the government (New Straits Times, 2017).

The report of Corruption Perception Index (CPI) in 2017 placed Malaysia at number 62 with the score of $47 \%$. This is not going well as Malaysia recorded a score of $49 \%$ and lying at 55 places in 2016. Meanwhile, the score for 2015 and 2014 was 50\% and 52\% respectively. As such, the past four years shows downward trends where Malaysia score for CPI is going down and this needs utmost attention to stop this trend from getting worse in coming years. According to the $\mathrm{CPI}, 0 \%$ means totally corrupt and $100 \%$ indicated clean from corruption activities. In tackling unhealthy issues of graft, unethical activities and power abuse, the government has set up audit team in each of its agencies. However, their functions are limited due to understaffing and inadequate support from top management (Ahmad, Othman, Othman \& Jusoff, 2009).

In fact, there are a lot of major issues considering the size of government staff which consists of 1.6 million employees. What makes it more complex, the core business of government machineries is dealing with delivering effective and efficient services. Therefore, it is a daunting task to overcome many unethical issues that inundate the public service in Malaysia. Moreover, the poor maintenance of public infrastructure and facilities gave bad image and perception to government staff in terms of accountability and integrity (Pawi, Juanil \& Yusoff, 2011). At the $13^{\text {th }}$ public service conference, it was noted that public service is still facing many issues ranging from poor service delivery, bureaucratic red tape, slow implementation of projects, lack of empathy towards customer apart from corruption cases (Najib Razak, 2008). The number of public complaints regarding public service performance from the year 2013 till 2016 displayed in Table 1 below:

Table 1: Number of public complaints from $2013-2016$

\begin{tabular}{|c|c|}
\hline Year & $\begin{array}{c}\text { Total } \\
\text { Complaints }\end{array}$ \\
\hline 2013 & 9,879 \\
\hline 2014 & 7,199 \\
\hline 2015 & 6,388 \\
\hline 2016 & 6,494 \\
\hline
\end{tabular}

Source: Official Portal Public Complaint Bureau, 2017

Table 1 shows that for the past four years, the daily average of complaints received regarding inefficient public service deliveries are at twenty one cases per day. This is quite high considering public servants have all the support at the workplace to perform their duties at the best possible manner. The negative scenario explained above can be associated with low level of engagement among government employees in carrying out their daily duties. Due to their disengagement at work, 
INTERNATIONAL JOURNAL OF ACADEMIC RESEARCH IN BUSINESS AND SOCIAL SCIENCES Vol. 8, No. 10, Oct. 2018, E-ISSN: 2222-6990 @ 2018 HRMARS

they work with no passion and complete their work without much interest. They are not serious to solve problems and answering enquiries from public. As mentioned by Gallup (2013), these disengaged employees are 'sleepwalking' throughout the day. The worse is some of them are involved in bribery and corruption activities that tarnish the image of their respective departments and the public service.

\section{Antecedents of Work Engagement}

Employees are not simply engaged in their tasks without certain factors that motivate them to do so. Here, work engagement is about individual construct which is closely related towards individual feeling. Hence, there is a strong justification to believe that engagement is strongly related to one's behavior, attitude and intention (Saks, 2006). In reality, there are many antecedents that influence the engagement level among workers. As work engagement is strongly related to psychology, emotional, willingness and energetic performance, there is tendency that employee can be engaged at certain time and becoming disengaged on the following days. Therefore, the main question is when do people feel or experience work engagement? As work engagement deals with vigor, absorption and dedication, it can be said that employees may experience different feeling of vigor, absorbed and dedication between days, weeks or months (Sonnetag, Dormann \& Demerouti, 2010).

As such, the first antecedent that can heavily influence work engagement level is personal resources. This term is related to individual resources at the workplace which enable him or her to perform exceptionally well. Personal resources can be described as positive attitude that is linked to resilience and the employee is able to perform well even though in difficult situations (Hobfoll, Johnson, Ennis \& Jackson, 2003). Therefore, the more personal resources an employee has at the workplace, we can expect many other positive results especially in terms of goals achieved (Judge, Bono, Erez \& Locke, 2005). Self-efficacy, self-esteem and resilience are examples of variables that are related to personal resources which are proven to have positive impact towards personal growth and organizational performance (Bakker \& Demerouti, 2008).

The second major antecedent that can boost engagement level among employees are job resources. In fact, many studies have confirmed that job resources are the major antecedents that significantly influence work engagement among employees. Job resources refer to various aspects which are related to physical, psychological, social and the organization that are functional in overcoming job demand impact, helping employees to achieve organizational goals and able to boost personal development (Schaufeli \& Bakker, 2004). Examples of job resources are social support, performance feedback and autonomy (Halbesleben, 2010). Studies by Xanthopoulou, Bakker, Demerouti and Schaufeli (2007) and Altunel, Kocak and Cankir (2015) found out that employees becoming more engaged when they have ample job resources.

The third component that has direct impact in fostering work engagement is leadership style. Undoubtedly, leadership is a key aspect that play pivotal role in determining the level of engagement as they have big influence towards their staff to stay motivated and engaged at work (Jones \& Harter, 2005). Therefore, leaders must act as a role model for engagement to flourish (Schaufeli \& Salanova, 2007). The leadership style that has close relationship towards increasing level of engagement at the workplace is transformational leadership (Sonnentag, Dormann \& Demerouti, 2010). Studies have 
INTERNATIONAL JOURNAL OF ACADEMIC RESEARCH IN BUSINESS AND SOCIAL SCIENCES Vol. 8, No. 10, Oct. 2018, E-ISSN: 2222-6990 @ 2018 HRMARS

also identified transformational leadership as key resources for the development of engagement among employees (Tims, Bakker \& Xanthopoulou, 2011). The main element of transformational leadership is about motivating employees to attain organizational goals and objectives. Transformational leadership also relies heavily on leaders to inspire, motivate and foster commitment among followers in ensuring the successful implementation of tasks (Bass \& Waldman, 1987). As work engagement involve both emotional and behaviour shown at work, the interaction of leaders and employees hold the key in ensuring employees are engaged throughout their job activities. Therefore, transformational leadership is proven to be an important leadership approach as they are able to motivate and 'energize' followers in fostering work engagement.

\section{Dimension of Personal Resources towards Work Engagement}

Personal resources act as both intrinsic and extrinsic motivation that motivates employees to perform during role performance (Bakker, 201). Some dimensions of personal resources that have strong influence in fostering work engagement are self-efficacy, self-esteem, resilience and optimism (Bakker and Demerouti, 2007; Hobfoll, 2001). In this $21^{\text {st }}$ century, public workforce is expected to be independent, have strong sense of achieving success, resilience and be optimistic in dealing with daily task. As such, public servants in Malaysia are expected to display certain strong characters in order to perform and meet the high expectations of people and stakeholders.

Three dimensions of personal resources that are strongly related to public service employees are self-efficacy, optimism and resilience. In principle, self-efficacy is the leading cast as it is associated with the inner belief of government employee to do the job and deliver the expected result. Then, optimism is chosen as it is closely related with employee confidence and ability to achieve positive result in the tasks given. Lastly, resilience is selected as it is a necessity for government staff to possess this character as it refers to their motivational aspect to bounce back from adversity and conflict towards delivering positive change as expected.

The first dimension of personal resources that is important for the public servant is self efficacy. Bandura (1977) defined this construct as the confidence or belief in one's ability to succeed at a particular task in a specific context. He further elaborated that this construct comes from four primary sources namely task master, vicarious learning, social persuasion and motivation of emotional or physical arousal. He stated that all these four sources will lead towards work engagement. For Stajkovic and Luthans (1998), they associated self-efficacy as "the employee conviction or confidence about his or her abilities to mobilize the motivation, cognitive resources and courses of action needed to successfully execute a specific task within a given context" (p. 241). Meaning to say, this construct is related on how an individual play his role in order to achieve tasks, goals and tackle challenges within their job scope. In fact, Stajkovic and Luthans (1998) found out that self-efficacy is the most important psychological mechanism that is able to produce positive work related outcomes such as engagement. Conversely, low efficacy is related to burnout, the antipode of work engagement. Gruman and Saks (2011) found out that self-efficacy does have positive influence on engagement. In fact, engaged employees are highly self-efficacious as they believe they are able to meet the demands they face in a broad array of context (Hasbesleben, 2010).

The second construct selected is optimism. In simple definition, optimism is associated with good things to happen to people (Carver and Scheier, 2002). Optimism is also connected with feeling 
in control and acts as buffer against stressful job demands (Kahn, 1992). According to Avey, Wernsing and Luthans (2008), those that possess high optimism level have strong belief that they will taste success regardless of their abilities. They believe in the positive potential regardless of previous experiences. In other words, an optimistic employee believes success is something they can replicate and control. Kahn's (1990) stated that optimism is related to psychological availability in which employees expect positive results. In this case, greater psychological availability will lead to higher level of work engagement through absorption. There are empirical results that proved optimism is positively related to work engagement. Citing an example, a study among female school principals in Netherlands found that resilience, self-efficacy and optimism contributed to work engagement (Bakker, Gierveld and Van Rijswijk, 2006). A study among breast cancer survivors identified that optimism was consistently related to cancer survivors' engagement (Hakanen and Lindbohm, 2008). Thus, this construct is important as it has direct impact towards public servant's motivation as it is able to instil the feeling of how important their task in ensuring all government initiatives and programmes are rolled out as planned.

Finally, the last construct that is vital for government staff to get engaged is resilience. According to Luthans (2002), resilience can be defined as 'positive psychological capacity to rebound, to bounce back from adversity, uncertainty, conflict, failure or even positive change, progress and increased responsibility'. In simple term, resilience is referring to the capacity of recovering quickly from difficulties and toughness. It is also reflects the individual's ability to react quickly in order to return to the good condition or back into shape. As such, employees that show resilience not only survive but thrive through positive adjustments in their current role performance (Masten \& Reed, 2002). More importantly, they are able to challenge their personal assumptions and even build up more resilience to face any other challenging issues at the workplace (Luthans \& Youssef, 2007). More importantly, individual with resilience can reduce the health damaging consequences and thus reduce disengagement (Khan, 1992). The truth is resilience has a direct and positive effect on individual energy that contributes significantly towards increasing engagement through vigor (Sonnentag, 2011). Hence, this element must be planted in each and every one of government staff.

\section{Dimension of Job Resources towards Work Engagement}

According to Schaufeli and Salanova (2007), having the satisfaction of basic needs at work in the form of job resources will contribute towards positive result and thus fostering engagement. Indeed, many studies indicate that job resources are the most important predictors of work engagement (Bakker \& Demerouti, 2007; Hakanen, Pethoniemi \& Toppinen-Tanner, 2008). Therefore, there is no doubt that job resources play pivotal role in fostering work engagement at workplace. Some of the dimensions of job resources that can predict work engagement are autonomy, social support, performance feedback and organizational climate (Halbesleben, 2010). For the public service, three dimension of job resources that a necessity for them to perform effectively are autonomy, feedback and supervisor support. These three constructs are chosen as working in public sector requires them to be empowered to make certain decisions (autonomy), getting constant advice (feedback) on their role performances and receiving continuous guidance from immediate bosses and leaders (supervisor support). 
The first dimension of job resources is a construct named autonomy. In simple terms, autonomy can be associated with the power granted by immediate supervisor for making decision within certain boundaries. This term is also associated with the independence and discretion available to the employees in determining the scheduling and procedures in performing job tasks. Crawford, Rich, Buckman and Bergeron (2014) associates the term 'autonomy' with freedom, independence and discretion of employee in scheduling and determining the procedure to carry out their tasks. The idea of providing this autonomy is a sense of ownership and control over work outcomes. Some scholars treat job autonomy as key facet of job design and characteristics that play critical elements of employee engagement (Albrecht, 2010; Gagne \& Bhave, 2011). Saks (2006) mentioned job design that provides employees with more autonomy and management interventions might be an area for future research. These variables form an important element for organizations to improve employee engagement situation which he addressed it as 'engagement gap'. As such, there is no doubt that autonomy is the key element that can boost engagement in the public service.

The second construct that is important for public service perspective is feedback. In general, feedback is the degree to which the employee receives clear and direct information about how effectively he or she is performing. Getting feedback regarding the tasks is essential for government employee to record improvement and thus attaining excellent performance. Crawford, Rich, Buckman and Bergeron (2014) define it as providing employees with direct and clear information about the effectiveness of their performance. As mentioned by Hackman and Oldham (1980), performance feedback increases job competence and lead to work engagement (Bakker \& Demerouti, 2008). Tims, Bakker and Xanthopoulou (2011) said employees that receive feedback from their supervisor most likely to be energetic and dedicated in their work. Research done by Schaufeli and Bakker (2004) also identified positive relationship between feedback and work engagement. Hence, feedback is an important dimension under job resources to increase the level of engagement among employees in the public service.

The third dimension is regarding supervisor support. This is another important element that is able to motivate government staff in delivering better performance. Schaufeli and Bakker (2004) reported that job resource such as supervisor support was positively related to engagement. Research undertaken by Baker, Demerouti and Schaufeli (2003) concluded that inadequately of resources such as lack of supervisor and social support was found to deter employees from accomplishing their goals, causing frustration, withdrawal behaviour, reduced organizational commitment and increased turnover intentions. In fact, Bakker and Demerouti (2008) which conducted studies among four different samples of Dutch employees found out that three job resources (performance feedback, social support and supervisory support) have positive relationship with work engagement (vigor, dedication and absorption). As the nature of working in public sector is full of challenges to meet high expectation from various group of people, getting continuous supervisor support is simply important. This will ensure employees in public service remain committed and engaged in their role performance.

\section{Dimension of Transformational Leadership towards Work Engagement}

The main elements of transformational leadership lies in its ability to motivate followers to accomplish more than what the follower planned to accomplish (Bass, 1999). Burns, the scholar that 
introduced this leadership style described transformational leadership as special relationship that bind leaders and followers in which they motivate each other towards attaining organizational goals. Meaning to say, this leadership style refers to those leaders that are able to inspire, motivate and foster commitment among followers in ensuring the successful implementation of tasks (Bass, Waldmam, Avolio \& Bebb, 1987). Due to its positive impact on personal and organizational outcomes, transformational leadership has captured the interest of many organizations (Tucker \& Russell, 2004).

According to Bass (1985), transformational leadership has four dimensions which are idealized influence, inspirational motivation, intellectual stimulation and individualized consideration. Idealised Influence can be referred as the situation when the leader is being seen as the role model for his followers. He or she is able to encourage the followers to share organization common visions and goals by providing a clear vision and a strong sense of purpose. The second dimension is intellectual stimulation that refers to the leader's ability to challenge their followers' ideas and values in order to solve the problems facing at workplace. Inspirational motivation forms the third dimension that can be best described as the behaviour of a leader that is able to express the importance of desired goals in effective ways. In other words, the leader displays effective communication skill that urges followers to perform their job roles in a meaningful way. The last dimension of transformational leadership is individualised consideration which can be defined as leaders who spend more time in teaching and coaching their followers based on individual basic skill and competency.

As work engagement involve both emotional and behaviour shown at work, the interaction of leaders and employees hold the key in ensuring employees are engaged throughout their job activities. If leaders lack dedication or absorption, followers will take a more lackadaisical approach in doing their own work. If leaders themselves are not trying new things, risking failure with new approaches, it will be difficult for followers to feel psychological safe to do so (Edmondson, 1999). Thus, leaders should act as a role model for engagement (Schaufeli \& Salanova, 2007).Therefore, transformational leadership is proven to be an important leadership approach as they are able to motivate and 'energize' followers in fostering work engagement.

\section{Significance of Having Engaged Employees in Public Service}

Public service employees in Malaysia are responsible towards implementing many transformation initiatives that have been introduced since 2009. All the above mentioned transformation programmes such as GTP, ETP, NKRA, NKEA and NBOS, to list a few will only be realized by having highly engaged public service workforce. Hence, having engaged employees is significant to achieve excellent performance. Public servants include all staff working either at federal, state, district level or local authorities. There are also government schemes that are large enough to have specific job categories such as the police, armed forces, teachers and medical staff. Excluding these big job categories, there are around two hundred fifty thousand government staff that are scattered around the country (New Straits Times, 2017).

Based on literatures, it can be concurred that engaged workers perform far better than disengaged workers. According to Schaufeli, Leiter and Maslach (2009), organizations badly need engaged employees in order to perform beyond the current level of doing task to thrive in this competitive world. This is due to the fact that people are simply the most important resource that 
any organization can have even though technology advancement is slowly reducing employees' functional roles. Anitha (2014) mentioned that having engaged employees are the key towards the successful outcome of their operations. She stressed that employees who show positive feeling, emotion, character and behaviour can have big impact toward organizational performance. This will lead towards the attainment of organizational goals.

According to May, Gilson, and Harter (2004), engaged employees demonstrated high energy and display enthusiastic characters in performing their duties. In the meantime, while employees may feel exhausted after long office hours, their tiredness is treated as pleasant due to positive achievements generated. In fact, those who are engaged in their daily tasks receive much praise from their co-workers in their work either involving in-role or extra-role performance. This situation that can be best described where engaged employees are able to perform up to the standard required and even surpass that expectation imposed on them from their bosses and organizations (Bakker, Demerouti \& Verbeke, 2004).

On top of that, engaged employees may also enjoy better health. Study by Hakanen, Bakker and Schaufeli (2006) involving the teaching profession in Finland revealed those engaged with their duties have positive association with self-rated health and workability. The same finding is reported from separate research done earlier by Schaufeli and Bakker (2004) among employees serving in different service organizations in Netherlands. Hence, these engaged employees are able to perform exceptionally well and thus provide their organizations with competitive advantage in the forms of higher productivity and lower turnover (Vance, 2006).

The advantages of having engaged employees are simply numerous. As mentioned by Agrawal (2015), she stated that engaged employees care for the organization, are loyal and willing to put extra efforts for organization growth and development. In addition, engaged employees are also satisfied with their work, appreciate their organizations and want to remain there for longer period. In general, these engaged employees are very proud to be associated with their organization and this is echoed in their service contribution in daily task (Agrawal, 2015). Based on the above evidence, having engaged government staff is essential for the government ministries to record the desired result. This is the critical area that needs to be addressed urgently as public employees remain the backbone for the successful implementation of various government projects and initiatives. Failure to recognise this issue will bring negative consequences to the overall performance of government machineries and contribute toward the inefficacy of public funds.

\section{CONCLUSION}

Public service cannot remain static and stagnant. The global landscape is becoming more chaotic and uncertain leading to slow economic growth, highly engaged workforce are the key in driving the public service. At the same time, the government realizes the importance of moving ahead with the agenda of transforming this country towards achieving an advanced nation status. As such, Malaysia is banking on the public servants to perform their duties effectively as they are the backbone of this nation if Malaysia is to achieve its developed nation status as outlined in Vision 2020

In fact, promoting work engagement remains as a huge challenge for government ministries and agencies not only in Malaysia but worldwide. As employees are diverse in nature, organizations need to identify certain factors and antecedents that are critical to get the best abilities from their 
employees. As such, the three identified antecedents that have proven to boost work engagement must be given proper attention in the form of personal resources, job resources and transformational leadership. These three variables must be studied deeper from their specific dimension as each construct has their own unique contribution towards fostering work engagement in the public service. Having motivated, happy and positive emotions at work will motivate public service employees to give their best shot for their self development and organizational excellence. Finally, there is no doubt that highly engaged workforce in public service hold the key in ensuring all government initiatives and programmes can be implemented successfully for the benefit of all Malaysians. Indeed, this is the hope and dream of every Malaysian.

\section{Corresponding Author}

Zaki Zakaria, Faculty of Educational Studies, University Putra Malaysia, 43400 UPM Serdang, Selangor Darul Ehsan, Malaysia. Email: zakizakaria7477@gmail.com.

\section{References}

Abdullah, A., Sulong, Z., \& Said, R. M. (2014). An analysis on ethical climate and ethical judgment among public sector employees in Malaysia. The Journal of Applied Business and Economics, 16(2), 133-143.

Agrawal, S. (2015). Predictors of employee engagement: a public sector unit experience. Strategic HR Review, 14(1/2), 57-68. https://doi.org/10.1108/SHR-07-2014-0044

Ahmad, N., Othman, R., Othman, R., \& Jusoff, K. (2009). The effectiveness of internal audit in Malaysian public sector. Journal of Modern Accounting and Auditing, 5(9), 53.

Albrecht, S. L., (2010). Handbook of employee engagement. Cheltenham: Edward Elgar Publishing Limited.

Altunel, M. C., Kocak, O. E., \& Cankir, B. (2015). The effect of job resources on work engagement: A study on academicians in Turkey. Kuram ve Uygulamada Egitim Bilimleri, 15(2), 409-417. https://doi.org/10.12738/estp.2015.2.2349

Anitha, J. (2014). Determinants of employee engagement and their impact on employee performance. International Journal of Productivity and Performance Management, 63(3), 308-323. https://doi.org/10.1108/IJPPM-01-2013-0008

Arnold B. Bakker, Simon L. Albrecht \& Michael P. Leiter. (2010). Key questions regarding work engagement. European Journal of Work and Organizational Psychology, 20(1), 4-28. http://dx.doi.org/10.1080/1359432X.2010.485352

Avey, J. B., Wernsing, T. S., \& Luthans, F. (2008). Can positive employees help positive organizational change? Impact of psychological capital and emotions on relevant attitudes and behaviors. The journal of applied behavioral science, 44(1), 48-70.

Bandura, A. (1997). Self-efficacy: The exercise of control. Macmillan Publisher. New York

Bakker, A. B. (2011). An evidence-based model of work engagement. Current Directions in Psychological Science, 20(4), 265-269. http://doi:10.1177/0963721411414534

Bakker, A. B., \& Demerouti, E. (2008). Towards a model of work engagement. Career Development International, 13(3), 209-223. http://doi.org/10.1108/13620430810870476 
INTERNATIONAL JOURNAL OF ACADEMIC RESEARCH IN BUSINESS AND SOCIAL SCIENCES

Vol. 8, No. 10, Oct. 2018, E-ISSN: 2222-6990 @ 2018 HRMARS

Bakker Arnold B., \& Demerouti Evangelia. (2007). The Job Demands-Resources Model: State of the Art. ResearchGate, 22(3), 309-328. https://doi.org/10.1108/02683940710733115

Bakker, A. B., Gierveld, J. H., \& Van Rijswijk, K. (2006). Success factors among female school principals in primary teaching: A study on burnout, work engagement, and performance. Diemen the Netherlands: Right Management Consultants.

Bakker, A. B., Demerouti, E., \& Verbeke, W. (2004). Using the job demands-resources model to predict burnout and performance. Human resource management, 43(1), 83-104. http://dx.doi.org/10.1002/hrm.20004

Bass, B. M. (1999). Two decades of research and development in transformational leadership. European journal of work and organizational psychology, 8(1), 9-32. http://dx.doi.org/10.1080/135943299398410

Bass, B. M., Waldman, D. A., Avolio, B. J., \& Bebb, M. (1987). Transformational leadership and the falling dominoes effect. Group \& Organization Studies, 12(1), 73-87.

Bass BM (1985) Leadership and performance beyond expectations. The Free Press, New York

Bazigos, M., \& Harter, J. (2016). Revisiting the matrix organization. McKinsey Quarterly.

Baldoni, J (2013). Employee Engagement Does More than Boost Productivity. Harvard Business Review. Retrieved from http://blogs.hbr.org/2013/07/employee-engagement-does-more/

Carver, C. S., \& Scheier, M. F. (2002). Control processes and self-organization as complementary principles underlying behavior. Personality and social psychology review, 6(4), 304-315.

Crawford, E. R., Rich, B. L., Buckman, B., \& Bergeron, J. (2014). The antecedents and drivers of employee engagement. Employee engagement in theory and practice, 57-81.

Edmondson, A. (1999). Psychological safety and learning behavior in work teams. Administrative science quarterly, 44(2), 350-383.

Eleventh Malaysia Plan 2016 - 2020. (2015). Anchoring Growth on People. Kuala Lumpur: Percetakan Nasional Malaysia Berhad

Gagné, M., \& Bhave, D. (2011). Autonomy in the workplace: An essential ingredient to employee engagement and well-being in every culture. In Human autonomy in cross-cultural context (pp. 163-187). Springer Netherlands

Gallup. (2013). Worldwide, 13\% of Employees Are Engaged at Work. State of the Global Workplace. http://doi.org/10.1073/pnas.0703993104

Gruman, J. A., \& Saks, A. M. (2011). Performance management and employee engagement. Human Resource Management Review, 21(2), 123-136. https://doi.org/10.1016/j.hrmr.2010.09.004

Hackman, J. R., \& Oldham, G. R. (1980). Work redesign. Reading, MA: Addison-Wesley

Hakanen, J.J., Bakker, A.B. \& Schaufeli, W.B. (2006). Burnout and work engagement among teachers. Journal of School Psychology, 43(6), 495-513. https://doi.org/10.1016/j.jsp.2005.11.001

Halbesleben, J.R.B. (2010). A meta-analysis of work engagement: Relationships with burnout, demands, resources and consequences. In Baker, A. B. and Leiter, M.P. (Eds.), Work engagement: A Handbook of essential theory and research (pp. 102-117). New York: Physhology Press

Hobfoll, S. E., Johnson, R. J., Ennis, N., \& Jackson, A. P. (2003). Resource loss, resource gain, and emotional outcomes among inner city women. Journal of personality and social psychology, 84(3), 632. http://psycnet.apa.org/doi/10.1037/0022-3514.84.3.632 
INTERNATIONAL JOURNAL OF ACADEMIC RESEARCH IN BUSINESS AND SOCIAL SCIENCES

Vol. 8, No. 10, Oct. 2018, E-ISSN: 2222-6990 @ 2018 HRMARS

Hobfoll, S. E. (2001). The influence of culture, community, and the nested-self in the stress process: advancing conservation of resources theory. Applied psychology, 50(3), 337-421. http://dx.doi.org/10.1111/1464-0597.00062

Hakanen, J. J., \& Lindbohm, M. L. (2008). Work engagement among breast cancer survivors and the referents: the importance of optimism and social resources at work. Journal of Cancer Survivorship, 2(4), 283-295.

Hakanen, J. J., Perhoniemi, R., \& Toppinen-Tanner, S. (2008). Positive gain spirals at work: From b resources to work engagement, personal initiative and work-unit innovativeness. Journal of vocational behavior, 73(1), 78-91. https://doi.org/10.1016/j.jvb.2008.01.003

Hakanen, J.J., Bakker, A. B., \& Schaufeli, W. B. (2006). Burnout and work engagement among teachers. Journal of School Psychology, 43(6), 495-513. https://doi.org/10.1016/j.jsp.2005.11.001

HR Asia. (2017). Malaysian employees are the least engaged among Asian markets. Retrieved from https://hrasiamedia.com/employees-in-malaysia-are-the-least-engaged-among-asianmarkets

Jimenez, D.-Z. (2016). White Paper Focusing on the Employee Segment of One for Higher Engagement and Productivity. International Data Corporation, June, 9), 1-8

Johari, J., Mit, D. A. C., \& Yahya, K. K. (2009). Construct validation of the job characteristics scale in the Malaysian public service setting. International Review of Business Research Papers, 5(3), 58-71.

Jones, J. R., \& Harter, J. K. (2005). Race effects on the employee engagement-turnover intention relationship. Journal of Leadership \& Organizational Studies, 11(2), 78-88. http://doi.org/10.1177/107179190501100208

Judge, T. A., Bono, J. E., Erez, A., \& Locke, E. A. (2005). Core self-evaluations and job and life satisfaction: the role of self-concordance and goal attainment. Journal of applied psychology, 90(2), 257. http://doi.org/10.1037/0021-9010.90.2.257

Kahn, W. A. (1992). To be fully there: Psychological presence at work. Human relations, 45(4), 321349.

Kahn, W.A. (1990). Psychological conditions of personal engagement and disengagement at work. Academy of Management Journal, 33(4), 692-724. http://doi: 10.2307/256287

Leiter, M. P., \& Maslach, C. (1988). The impact of interpersonal environment on burnout and organizational commitment. Journal of organizational behavior, 9(4), 297-308. http://dx.doi.org/10.1002/job.4030090402

Luthans, F., \& Youssef, C. M. (2007). Emerging positive organizational behavior. Journal of management, 33(3), 321-349. http://dx.doi.org/10.1177\%2F0149206307300814

Luthans, F. (2002). Positive organizational behavior: developing and managing psychological strengths. Academy of Management Executive, 16, 57-72. http://doi: 10.5465/AME.2002.6640181

Macey, W.H. and Schneider, B. (2008). The meaning of employee engagement. Industrial and Organizational Psychology: Perspectives on Science and Practice, 1(1), 3-30. http://doi:10.1111/j.1754-9434.2007.0002.x

Masten, A. S., \& Reed, M. G. (2002). J.(2002). Resilience in development. Handbook of positive psychology, 74-88 
INTERNATIONAL JOURNAL OF ACADEMIC RESEARCH IN BUSINESS AND SOCIAL SCIENCES

Vol. 8, No. 10, Oct. 2018, E-ISSN: 2222-6990 @ 2018 HRMARS

May, D.R., Gilson, R.L., \& Harter, L.M. (2004). The psychological conditions of meaningfulness, safety and availability and the engagement of the human spirit at work. Journal of Occupational and Organizational Psychology, 77(1), 11-37. https://doi.org/10.1348/096317904322915892

Najib Razak. (2008). 13th Civil Service Conference. In Taking Charge: Leadership in the Public Service. Retrieved from https://www.najibrazak.com/en/news_archive/13th-civil-serviceconference/

New Straits Times (NST). (2016, November 11). 52pc of employees unhappy. Prime News, p 22

New Straits Times (NST). (2017, March 8). MACC: Half of civil servants found guilty of graft are under 40. Retrieved from: https://www.nst.com.my/news/2017/03/218671/macc-half-civilservants-found-guilty-graft-are-under-40

New Straits Times (NST). (2017, February 23). Is the public service really bloated? Opinion, p. 19

Pawi, S., Juanil, D. M., Yusoff, W. Z. W., Malaysia, O., Sipan, I., \& Shafie, F. (2012). Property Tax Performance of Local Authorities in Malaysia. Journal of Modern Accounting and Auditing, 8(4), 461.

Official Portal Public Complaint Bureau, Prime Minister Department. (2017). Retrieved from http://www.pcb.gov.my/en/complaint/statistics-by-year

Public Sector Transformation Division. (2014). Transforming Public Service in Malaysia: Guidelines for Developing a Transformation Plan. Public Service Department, 30. Retrieved from http://portaladmin.jpa.gov.my/index.php?

Rosli, M.H., Aziz, M.A. bin A., Mohd, F., \& Said, J. (2015). Integrity Systems in Malaysia Public Sector: An Empirical Finding. Procedia Economics and Finance, 28 (April), 260-265. https://doi.org/10.1016/S2212-5671(15)01109-0

Saks, A. M. (2006). Antecedents and consequences of employee engagement. Journal Managerial Psychology, 21(7), 600-619. http://doi.org/10.1108/02683940610690169

Salanova, M., Agut, S., \& Peiró, J. M. (2005). Linking organizational resources and work engagement to employee performance and customer loyalty: the mediation of service climate. Journal of applied Psychology, 90(6), 1217. http://dx.doi.org/10.1037/0021-9010.90.6.1217

Schaufeli, W.B. and Arnold B. Bakker. (2010). Defining and measuring work engagement: Bringing clarity to the concept. In Baker, A. B. and Leiter, M.P. (Eds.), Work engagement: A Handbook of essential theory and research (pp. 10-24). New York: Psychology Press

Schaufeli, W. B., Leiter, M. P., \& Maslach, C. (2009). Burnout: 35 years of research and practice. Career development international, 14(3), 204-220. https://doi.org/10.1108/13620430910966406

Schaufeli, W. B., \& Salanova, M. (2007). Efficacy or inefficacy, that's the question: Burnout and work engagement, and their relationships with efficacy beliefs. Anxiety, stress, and coping, 20(2), 177-196. http://dx.doi.org/10.1080/10615800701217878

Schaufeli, W. B., \& Bakker, A. B. (2004). Job demands, job resources, and their relationship with burnout and engagement: A multi-sample study. Journal of organizational Behavior, 25(3), 293-315. http://doi:10.1002/job.248

Schaufeli, W. B., Pinto, A. M., Salanova, M., \& Bakker, A. B. (2002). Burnout and engagement in university students: A Cross-National Study. Journal of Cross-Cultural Psychology, 33(5), 464481. http://dx.doi.org/10.1177\%2F0022022102033005003 
Schaufeli, W. B., \& Bakker, A. B. (2001). Work and well-being: Towards a positive Occupational Health Psychology. Gedrag and Organisatie, 14(5), 229-253.

Sonnentag, S. (2011). Research on work engagement is well and alive. European Journal of Work and Organizational Psychology, 20(1), 29-38. http://dx.doi.org/10.1080/1359432X.2010.510639

Sonnetag, S., Dormann, C. and Demerouti, E. (2010). Not all days are created equal: The concept of state work engagement. In Baker, A. B. and Leiter, M.P. (Eds.), Work engagement: A Handbook of essential theory and research (pp. 25-38). New York

Stajkovic, A. D., \& Luthans, F. (1998). Self-efficacy and work-related performance: A meta-analysis. Psychological bulletin, 124(2), 240.

Tims, M., Bakker, A. B., \& Xanthopoulou, D. (2011). Do transformational leaders enhance their followers' daily work engagement? The Leadership Quarterly, 22(1), 121-131. https://doi.org/10.1016/j.leaqua.2010.12.011

Tucker, B. A., \& Russell, R. F. (2004). The influence of the transformational leader. Journal of Leadership \& Organizational Studies, 10(4), 103-111.

Vance, R. J. (2006). Employee Engagement and Commitment: A Guide to Understanding, Measuring, and Increasing Engagement in your Organization. SHRM Foundation's Practice Guidelines. Alexandria, VA, 22314.

Xanthopoulou, D., Bakker, A. B., Demerouti, E., \& Schaufeli, W. B. (2007). The role of personal resources in the job demands-resources model. International journal of stress management, 14(2), 121. http://dx.doi.org/10.1037/1072-5245.14.2.121 